\title{
Budgetary Control and Performance in Public Corporations in Osun State
}

\author{
${ }^{1}$ Olaoye, Festus Oladipupo, ${ }^{2}$ Ogunmakin, Adeduro Adesola \\ ${ }^{I}$ Department of Accounting,Faculty of the Management Sciences, Ekiti State University, Ado-Ekiti, Nigeria \\ ${ }^{2}$ Department of Accounting,Faculty of Management Sciences, Ekiti State University, Ado-Ekiti, Nigeria
}

\begin{abstract}
This study examined the budgetary control and performance in government parastals in Osun state, Nigeria. The primary objective was to determine the relationship between revenues and expenditures estimates and actuals. Five parastals were sampled using budgetary performance for five fiscal years (2007-2011). The Pearson Product Moment Correlation was used to determine the existence of relationship. Findings revealed that there existed strong and weak negative relationship in the revenues and expenditures of the establishments over the periods selected, viz: Agricultural Corporation -0.28 (weak), Broadcasting Corporation -0.58 (strong), College of Education -0.41 (weak), Property Development Corporation -0.64 (strong) and Water Corporation 0.33 (weak). It is the opinion of this research to recommend that the budgeting process in those corporations needs a re-engineering to reflect the true picture of their fiscal ability and to be a guide to action and performance.
\end{abstract}

\section{Introduction}

Budget can be defined as a detailed financial statement that shows details of anticipated revenue and prepared expenditure, (Yakubu ,2011). Is also a forecast of expenditures and revenue for a specific period of time; usually one year. The word budget originated from a French word bougette meaning little bag. In Britain, the word was used to describe the leather bag in which then chancellor of the exchanger used to carry to the parliament the statement of governments needs and sources as describe by several thought of consensus, the budget became the document contained in the bag which represent plans of government expenses in money and submitted to legislative for approval, (Abdullahi \& Angus, 2012).

According to Olurankinse (2012), budget making and budget implementation involve the process of identification of public needs and the determination of the quality of goods and services to satisfied these need through the political process, by economic analysis with the overall developmental plan objective. Government prepares budget in form of public policy to serve as a driving force through which are mission could be achieved. As good as our budget is, the performance of which can be measured in terms of accomplishment is noting to right home about. Budget accomplishment is far from reality and the disparity between budget and accomplishment are so wide and kept on abating as years pass by.

The government plays a leading role in shaping and development of any nation and giving there explicit important, it is necessary to provide a suitable frame work to enable the achievement of this noble-role. This is accomplished through the apparatus public administration, a field which refers to the manner in which federal, state, and local institutions with their procedural, legal, regulatory, financial, human resources and asset aspect are organized, institutionalized and managed with respect to regulatory, revenue generation, speeding and procurement functions, and the provision of such services as defense, social service, and economic infrastructures, (Kenneth, 2012).

Public sector according to Olurankinse (2012) simply refers to the part of the economy that is controlled by the government for the purpose of basic government services. These basic services that the government needs to provide is so enormous due to increase in the number of people they service. As economics will put it "human wants are unlimited, but the means to satisfy them are limited", this therefore calls for the use of an efficient management tools that will harness the limited resources for optimal use. One of the machineries of government that can be use for this purpose is budget.

\section{Problem Statement}

Government prepares budget in form of public policy to serve as a driving force through which are mission could be achieved. As good as our budget is, the performance of which can be measured in terms of accomplishment is noting to right home about, (Olurankinse, 2012). Budget accomplishment is far from reality and the disparity between budget and accomplishment are so wide and kept on abating as years pass by. It is based on the above premise that the study sought to examine the degree of relationship that exist between expenditure and revenue of some selected public corporations in Osun state. The selected public corporations 
are: Property Development Corporation, Broadcasting Service Corporation, Water Corporation, Agricultural Development Corporation and College of Education Ila

\section{Objective Of The Study}

In budgeting, the focus is not only to prepare the budget, but more importantly to have a follow up operation for budgeting and to act according to known data. In addition, budget is also known as a financial expression of a countries plan for a period of time, (Falk, 1994). Therefore, the specific objective of this study is to look at the extent of relationship that exists between the expenditure and revenue generated by the Osun state public corporations.

\section{Research Hypotheses}

$\mathbf{H}_{\mathbf{0}}$ : There is a relationship between expenditure and revenue of public corporations.

$\mathbf{H}_{\mathbf{1}}$ : There is no relationship between the expenditure and revenue of public corporations.

\section{Review Of Literature}

Budget had been defined as accounting device used to plan and control resources of operational department of government and divisions, (Abdullahi \& Angus, 2012). Budget documents are the most important manifestation of public; they record the outcome of the political process: winners and losers of the political competitions. They delineate government total service effort. As political documents, budget allocates scarce resources among competing social and economic needs. As managerial documents, they specified the wants and means for providing for government services. By establishing the cost for various programmes they set up, the criteria by which government programmes are to be review and evaluated. Budget has become the main instrument by which government attempt to manage economic growth and development. Budget become accounting instruments by which officials are held accountable for what government does and does not manage to accomplish, (Yakubu, 2011). Public Budget preparation is one of the tedious tasks of any country. The preparation process for the annual budget involved a great deal of energy, time and expense. Hence, it is important that a country most be able to follow accurately all the methods of preparing an annual budget. Budgeting is defined as a form of financial planning and source budget is utilized to impose the strategy of a country. Consequently, a budget is composing of different functional budget that could help a country for such development such as agriculture, technology, tourism, and other budget. The combination of each functional budget made up the capital budget, master budget and even the cash flow budget which consist income and balance sheets, (Smith \& Megeary, 1997).

In budgeting, the focus is not only to prepare the budget, but more importantly to have a follow up operation for budgeting and to act according to known data. In addiction, budget is also known as a financial expression of a countries plans for a period of time, (Falk, 1994). It tells where and how the organization we spend money and where the money will come from to pay these expenses. Budget also set limit. Imagine how chaotic an industry or country will be if everyone was allowed to spend as much as they wished on whatever the wanted. Besides setting limit, budget also enables the assurance that the most important needs of a country are meet first and less important needs are deferred until there are sufficient funds in which to pay for them, (Andrews and Hill, 2003).

Even though budget preparation is not the sole things that need consideration in budgeting, the bases of it are still needed in other to have at least close estimation. According to (Abogun and Fagbemi, 2012), the effectiveness of budgeting has a link with the Level of environmental volatility. It means that, how effective budgeting would be in controlling the activities of any organization depends largely on the environmental volatility under which such budget is operated, (Olurankinse et al, 2008), an assessment of the budgeting process in the public sector leaves much to be desired. The practice today is that a certain percentage is added to previous period's budget to arrive at current budget figures without reference to the environmental inhibitions being encountered or the realities of present day situation. The budgets are centrally prepared and the result passed down the line for all and sundry to implement without questions.

Government use budgets as a guiding tool for planning and control of its resources, be it financial or otherwise. The use of budget involves knowing how much money you earn and spend over a period, particularly one year. When a budget of an establishment, department or ministry is created, it means creating a plan for spending and saving money, (Abdullahi and Augus, 2012).

Abokun \& Fagbemi (2012), explain that another use of budget for control purpose is in evaluating performance. They argue that organizational plans are carried out by people, thus, control is exercise not over operations, revenue, costs, but over the persons responsible for those operations and the related revenue and expenses. According to Olurankinse et al (2008), budgeting in the early stage of its evolution was primarily concerned with serving the purpose of legislative accountability 


\section{Research Design}

\section{Methodology}

The method of analysis for this study is the use of simple correlation analytical techniques, which is used to compute and establish a relationship between budget allocation or expenditure and revenue generated by the five selected Government Parastatals in Osun state of Nigeria, based on the research work of (Akintoye, 2008), (Olurankinse, 2012) \& Abokun and Fagbemi, 2012). We shall make use of secondary data precisely the budgetary allocation to each of the parastatals, state annual budget for each of the year under review and the revenue generated by each of the parastatal for the year under review.

The selected parastatals are: Osun State Broadcasting Corporations, Osun State Water Corporations, Osun State Property Development Corporation, Osun State Agricultural Development Corporations and Osun State College of Education.

\section{Results And Discussion}

\section{Agricultural Development Corporation}

The relationship that exists between the expenditure and revenue of agricultural development corporation as one the Osun state public corporation is determined using correlation coefficient. From the data collected on expenditure and revenue on the above corporation, it was discovered that coefficient of correlation is -0.28 . This result showed that negative and weak correlation exists between expenditure or budget allocation and revenue generated by agricultural development corporation. Thus, there is no justification between budget allocation and revenue generated.

\section{Broadcasting Service Corporation}

The degree of relationship that exists between the budget allocation and revenue generated broadcasting service corporation using Pearson correlation coefficient is -0.58 . This result implies a negative and a strong correlation exist between the budget allocation and revenue generated by the corporation. The implication of this result is that, as the budget allocation is increasing the revenue generated is decreasing. Hence, there is a call for serious check.

\section{College of Education}

The extent of relationship that exist between the budgetary allocation and revenue generated by the Osun State College of Education, Ila using Pearson correlation coefficient is -0.41 . This implies the existence of negative and weak relationship between the amount of money received and the income generated by the Osun State College of Education. This means that the level of accountability and transparency in government corporations need an urgent improvement.

\section{Property Development Corporation}

The degree of relationship that exist between the expenditure and revenue generated by the property development corporation as measured using Pearson correlation coefficient is -0.64 . This showed that there is a negative and a strong correlation or relationship between the corporation expenditure and revenue generated. Thus, there is a need for investment in properties that can bring improvement to people's life as well as development to the state.

\section{Osun state water corporation}

The extent of relationship that exists between the budgetary allocation and revenue generated by the Osun state water corporation was measured using Pearson correlation coefficient. From the analysis carried out, it was revealed that the correlation coefficient is -0.33 . This implies that negative and weak correlation exists between budget allocation and revenue generated by the Osun state water corporation. Thus, there is a need for an improvement in water supply by Osun state government through the water corporation.

\section{Concluding Remarks}

This study investigated the budgetary control and performance in public corporations in Osun State of Nigeria for the period between 2007 - 2011 using the budget allocation and revenue generated by each of the corporation under investigation.

The results of the analysis revealed that there exists a weak relationship between the expenditure or budgetary allocation and the revenue generated by the agricultural development corporation, college of education and Water Corporation. Also, it was discovered that there is existence of strong correlation or relationship between budgetary allocation and revenue generated by the Osun State broadcasting Service Corporation and property Development Corporation. The implication of this result is that, revenue generated by 
each of the public corporation had not justified the budgetary allocation to each of the corporations during the period under consideration for this research.

The study therefore recommends that investment in agriculture and properties that will improve the well being of the citizen as well as development to the state must be accorded a high priority. Policy reorientation on when and how government establishments and corporations spend there budgetary allocation, the level of accountability and transparency of the corporations must be given an urgent attention so as to checkmate their excessiveness.

\section{References}

[1]. Abdullahi, A.M \& Angus, O.U. (2012). Budget in Nigeria Public Sector: Need for Balanced Scorecard Perspective. International Journal of Finance and Accounting, 1(2): 1-6

[2]. Olurankinse, F. (2012). Due Process and Budget Implementation: An Evaluation of Nigerian Public Sector Auditing. Asian Journal of Finance and Accounting. Vol. 4, No. 2, ISSN 1946-052X

[3]. Akintoye, I.R. (2008). Budget and Budgetary Control for Improved Performance: A Consideration for Selected Food and Beverages Companies in Nigeria. European Journal of Economics, Finance and Administrative Sciences. ISSN 1450-2275, Issue 12 (2008).

[4]. Kenneth, E.O. (2012). Fiscal Accountability Dilemma in Nigeria Public Sector: A Warning Model for Economic Retrogression. Research Journal of Finance and Accounting. Vol. 3, No. 6, ISSN 2222-1697.

[5]. Yakubu, S.A. (2011). Public Budget and Budgetary Control in Nigeria. Journal of Business and Organizational Development, vol. 3

[6]. Abogun, S \& Fagbemi, T.O. (2012). The Efficacy of Budgeting as a Control Measure in Developing Economics: A Study from Nigeria. Asian Social Science Journal, vol. 8, issue 1, p176. 